\title{
Impact of Execution Planning on Agile Project Success with Mediating and Moderating Mechanism
}

\author{
Namra Mubarak, Muhammad Rafique, Asim Riaz Ranjha
}

\begin{abstract}
The present study investigated the impact of execution planning on agile project success with the mediating role of information sharing and moderating role of organization effectiveness because of the highlighted importance of agile methodology in the project industry due to its interactive customer collaborative approach. For this purpose, data were collected from software industry in Pakistan who utilize agile methodology in their projects. 300 completed questionnaires were received from the distributed and 280 were utilized for data analysis. The results delineated that execution planning has positive and significant relationship with agile project success. Similarly, the results indicated that information sharing mediates the relationship between execution planning and agile project success. Furthermore, the data showed that organization effectiveness moderates the relationship of execution planning and information sharing. Lastly, we conclude with theoretical and practical implications as well as future research directions.
\end{abstract}

Keywords : Execution planning, Information sharing, Organization effectiveness, Agile project success

\section{INTRODUCTION}

The role of agile methodology in IT based projects is gaining attention of researchers during the last few decades due to the failure of IT projects. This failure is generally because of mismatch between the traditional project success factors which don't fit in the IT based projects [1]. Failure of IT projects is astonishing. This failure leads to the shift of traditional approaches with the agile methodology [2]. Agile methods are reported to have more success rate, If there are fixed plans they cause delays, imperfections and dissatisfaction of the employees. So the basic principle of agile project management is not as to plan and then execute it is a shift from this strategy. The agile projects need more planning [3]. Generally, it consists of different layers of planning it is usually considered to be a cyclic process which runs between gathering customer data, planning, designing, testing and implementing [4].

As per recent studies the planning information is shared

Revised Manuscript Received on October 31, 2019.

* Correspondence Author

Namra Mubarak *, Department of management and social sciences, Capital university of science and technology, Islamabad, Pakistan. Email: namra_mubarakk@yahoo.com

Muhammad Rafique, Department of management and social sciences, Capital university of science and technology, Islamabad, Pakistan. Email: khanfr353@gmail.com

Asim Riaz Ranjha, Department of operations, management, SAP Asim.Riaz1993@gmail.com International Private Limited, Pakitan Town, Islamabad, Pakistan. Email:

among the team who would then execute that plan. Sharing of the information affects the performance in IT projects [5]. Recently Companies are considering the factor of sharing information for successful implementation of agile projects [6]. Different organizational work practices of sharing knowledge affect the agility practice in software development industry so it's certainly very much important that affective practices should be employed [7]. Organizational effectiveness requires new systems, techniques, methodologies and strategies to modify mental models of employees to handle new demands [7]. Literature on Organizational effectiveness inquires its impact on the success of the project and suggests that the organization should assist its employees to inculcate better performance for affective results in information technology projects [9]. Along the rapid exploration of this topic, the studies generally ignore its role at project execution phase, this gap still remains unexplored. The present study is indented to find answers for some questions. Question 1: How execution planning affects agile project success? Question 2: What is the importance of information sharing toward agile success? Question 3: How organization effectiveness affects the agile success?

Study provides evidence on the cause that whether there is need to focus on planning phase of the project or the planning should be conducted along the execution phase by sharing the planned information and how the organization and effectiveness affects the overall success of any project.

\section{LITERATURE REVIEW}

\section{A. Execution planning and agile success}

The outputs of the project planning phase include the project requirements, the project schedule, and the project management plan [10]. Agile advocates adaptive planning, evolutionary development, early delivery, and continuous improvement, and it encourages rapid and flexible response to change."[11] .Adaptive planning which is being studied as execution planning in this study. Most of the projects using the agile methodology start with the proper adaptation of planning by the word adaption it's obvious that strategic plans are not the plans to be followed. Agility is considered to be a coin shifting from traditional approaches toward those ones which are rigorous responses of the change and adopt to customer requirements[12]. As agility is to respond to changes it is impossible for the organizations to work with the forward planning. 
It should be adaptive at intense speed to respond to changes[13]. Importance of planning can be identified from the fact that along other crucial aspects required to be kept in mind planning is one of the main factors in success of agile methodology[14]. As the story cards are written by the onsite customers so it is ensured that customer responsiveness is being kept in mind [15].

Same is witnessed in another research that responding to customers by following a strict plan is very difficult. Such plan can only be followed by collaborating with the customers as its making the plan flexible i.e. not exactly a step by step approach to be followed [16]. Agile methods focus on a shift from upfront planning to agile methods [17]. Many agile planners allocate some of the time for the allocation of iteration planning to be done for responding to change regardless of the upfront plan made [18] because changes in the market limit the company's capability to follow the planned state [19]. Counter arguments suggest that strategic planning is given due importance as it is considered as a key element in long term performance of the organization [20]. Some studies contradict the relationship and state it's not must to do proper structured planning for the agile projects but still internalized plans are prepared [21]. Another study indicates that planning was much helpful in achieving success.So, we propose that

H1: Project Execution planning is positively and significantly associated with agile project success..

\section{B. Information sharing mediates the relationship between execution planning and agile success}

According to [22] the most key aspect of agile industry is sharing of information, if the information is not shared success can't be achieved. Information can only be shared by constant sessions, collaborations and meet ups so all these collaborations need knowledge sharing to engage with the right amount of knowledge [23]. We have to cope with the changes and share the customer updations by extensive sharing [24]. Sharing right amount of information ensures effective collaboration between the team members and the customers [25]. Degree to which the information is shared among the buyers can help to attain performance in diverse ways i.e. usage, output and flexibility [26].

Participants should perform some pre-defined set of activities so that for better planning information could be shared all the way through these activities [27] because information sharing highlights the risks of the project and helps the management to resolve those issues which could be crucial for the project [28]. We require sooth and seamless information systems for effective production to avoid uncertainty which can occur due to lack of information sharing [29]. Planning is done to meet the demands of the customers and information is shared among the employees regarding the requirements of the customers so that same type of product could be delivered to the end customers [30]. Planning brings together members from varying backgrounds to share information [31]. There should be well connected social network to effectively share information informally and to cut the cost of communication in agile software development projects [32]. In another study, it is highlighted that planning helps to achieve mass customization in industry and the amount and quality of information also matters regarding this relationship [33]. Information is the most crucial thing in planning and agile success [34]. IT capabilities are mainly dependent on the information sharing and retrieval [35]. So, from all above stated literature it can be predicted that $\mathrm{H} 2$ : There is a positive association between execution planning and Information sharing. H3: There is a positive association between Information sharing and agile success. H4: Information sharing mediates the relationship between execution planning and agile success.

\section{Moderating role of organizational effectiveness between information sharing and agile success}

According to [36] planning requirements of each organization are different. Effectiveness of the organization helps to sustain the business organization to adapt to innovative organizational changes and to adopt the agile methodology technique in the business processes for effective and better performance [37]. Effectiveness of sharing knowledge is done to advocate the frequency of the information that needs to be communicated among the project team [38]. It's been reported that bringing change in the organization through agility is the most important breakthrough these days so that the customer collaboration could be increased to achieve effective performance [39]. Empirical evidence is provided by [40] that more the organization would be rigorous to organizational changes the more it would be enriched by knowledge sharing and it would be more effective to produce better performance of the software development projects. On the base of previous literature, the present study is attempting to develop and test the following hypothesis;

H5: Organization effectiveness moderates the relationship between Information sharing and Agile success; such that if Organization effectiveness is high than the relationship between Information sharing and Agile success would be weakened.

\section{R RESEARCH METHODOLOGY}

To test the hypothesis data were collected from different organizations using agile methodology to carry out their projects. To get a clear picture of the issue we selected respondents from both public and private sector organizations. Respondents were targeted who serve the agile projects. Demographic data was also collected indicating age, education, experience and gender. The population of this research-included project based organizations from major cities of Pakistan and convenience sampling was used to serve the purpose. 300 questionnaire were distributed and 280 were used for data analysis which is sufficient according to the standard required sample size. Demographics indicates that most of the respondents were male accounted for $57.1 \%$ and female were $42.9 \%$. Most of the respondents were aged in between $26-33$ accounted for $37.1 \%, 23.6 \%$ and $20.7 \%$ were between 18-25 and 34-41 respectively. 
Moreover, most of the respondents had qualification of Master constituted for $41.8 \%, 31.4 \%$ and $24.6 \%$ had qualification of MS/M.Phil and Bachelor respectively. Furthermore, majority of the respondents $55.4 \%$ had experience between $0-5.25 .4 \%$ and $13.6 \%$ had an experience between 6-10 and 11-16 respectively. In this study close ended questionnaires were used to measure four variables. 5point Likert scale was utilized to measure all variables. Execution planning was measured through 4 items scale developed by [41] For information sharing six items scale developed by [42] was adopted. Likewise, organization effectiveness was measured by utilizing [43] Agile success was measured through 6 items scale developed by [44] Agile success was measured in both market readiness and customer satisfaction perspective regarding the required product.

\section{RESULTS}

\section{A. Statistical test for data analysis}

Table 1 represents the correlation of different variables under study. It shows the association between different variables. Execution planning is significantly correlated with project success $(\mathrm{r}=.456, \mathrm{p}<.01)$, Organization effectiveness $(\mathrm{r}=.323, \mathrm{p}<.01)$. Information sharing is significantly correlated with Organization effectiveness $(\mathrm{r}=.342 * *, \mathrm{p}<.01)$. And Organization effectiveness is significantly correlated with Agile project success $(\mathrm{r}=392 * *, \mathrm{p}<.00)$.

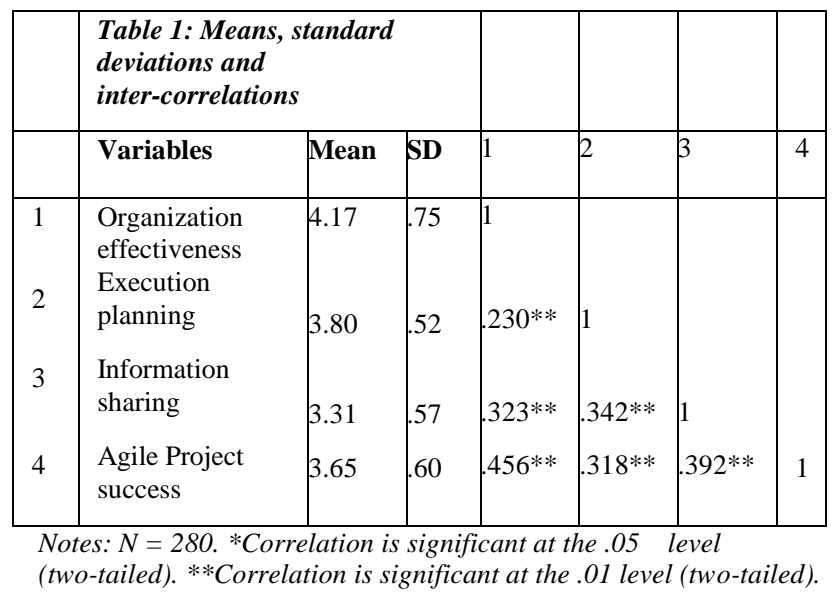

\section{B. Hypothesis Testing}

For hypothesis testing analysis were conducted on Spss 22.0. Hypothesis 1 states that execution planning has positive and significant relationship with agile project success. The results provide strong justification as indicated by regression co-efficient indicates that $(B=.29, p=.00)$. Similarly, the results provide strong justification for hypothesis 2 that execution planning has positive and significant relationship with information sharing as indicated by $(B=.19, p=.00)$. Moreover, the regression coefficient $(B=.15, p=.00)$ indicates support for hypothesis 3 , that information sharing has significant relationship with agile project success. Hypothesis 4, states that information sharing mediates the relationship between execution planning and agile project success. The results provide support as indicated by the indirect effect upper and lower limit (0.08 and 0.12) as both has same sign means that there is no zero between them. For hypothesis 5 , the interaction term $(\mathrm{B}=-.2637, \mathrm{p}=.00)$ provides support that organization effectiveness moderates between execution planning and agile project success such that it weakens the relationship.

\begin{tabular}{|c|c|c|c|c|}
\hline \multicolumn{5}{|c|}{ Table 2. Hypothesis Testing } \\
\hline Paths & $\boldsymbol{B}$ & $S E$ & $T$ & $P$ \\
\hline $\begin{array}{l}\text { Execution Planning } \\
\text { Agile Project Success }\end{array}$ & .29 & .06 & $\begin{array}{l}4.77 \\
6 \\
\end{array}$ & .00 \\
\hline $\begin{array}{l}\text { Execution Planning } \\
\text { Information Sharing }\end{array}$ & .19 & .05 & $\begin{array}{l}3.53 \\
3 \\
\end{array}$ & .00 \\
\hline $\begin{array}{l}\text { Information Sh } \\
\text { Agile Project S }\end{array}$ & .15 & .07 & 2.09 & .03 \\
\hline $\begin{array}{l}\text { Int_Term } \\
\text { Agile Project Success }\end{array}$ & -.26 & .09 & 2.82 & .00 \\
\hline ults for & \multicolumn{2}{|c|}{$\begin{array}{l}\text { UL } 95 \% \\
\text { CI }\end{array}$} & \multicolumn{2}{|c|}{ LL $95 \%$ CI } \\
\hline & \multicolumn{2}{|c|}{.12} & \multicolumn{2}{|l|}{.09} \\
\hline \multicolumn{5}{|c|}{$\begin{array}{l}\text { Note: Un-standardized regression coefficient reported. Bootstrap } \\
\text { sample size } 5000 . L L=\text { lower limit; } C I=\text { confidence interval; } U L= \\
\text { upper limit. } N=280 \text {, Control variables were included and } * P<.05 ; * * \\
P<.01\end{array}$} \\
\hline
\end{tabular}

Figure 3 shows the Interaction of organization effectiveness and information sharing on agile project success.

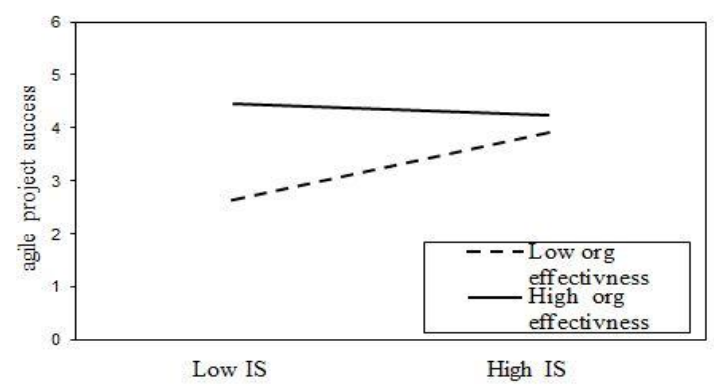

Fig

3. High and low level of organization effectiveness and information sharing with one standard deviation above and below mean respectively

\section{DISCUSION}

We find full support regarding our proposed relationship as it is evidenced that most of the software projects use agile methodology because they need certain specifications [45] so they need execution planning rather than upfront planning because in the software development plan we have to work with planning on each iteration so that nothing could go wrong [46]. Though few studies negate the relationship by providing evidence that upfront planning is a crucial factor in the industry for long term [47] and structured planning is more suitable for such projects [48]. This study elucidates the mediating role of information sharing between the proposed relationship followed by full support of the previous literature which establishes the relationship of information sharing with execution planning and agile success and considered it as one of the essences for productive performance [49]. Our investigation also proves the moderating role of organization effectiveness depicting significant effect on the agile project performance and other fields [50] Which is negating some previous researches which say that, it also helps to manage uncertainty and ambiguity to come up successfully in the market to 
become more customers focused and oriented [51] Likewise, there are many other factors which are unexplored related to the agile methodology technique so those factors should also be studied which are impacting the agile industry and why different industries haven't still adopted the agile methodology even its worth doing.

\section{REFERENCES}

1. Neves, F., Borgman, H., \& Heier, H. (2017, January). Success Lies in the Eye of the Beholder: A Quantitative Analysis of the Mismatch Between Perceived and Real IT Project Management Performance. In Proceedings of the 50th Hawaii International Conference on System Sciences. https://doi.org/10.1109/hicss.2016.745

2. Dybå, T., \& Dingsøyr, T. (2008). Empirical studies of agile software development: A systematic review. Information and software technology, 50(9-10), https://doi.org/10.1016/j.infsof.2008.01.006

3. Koskela, J., \& Abrahamsson, P. (2004, November). On-site customer in an XP project: Empirical results from a case study. In European Conference on Software Process Improvement (pp. 1-11). Springer, Berlin, Heidelberg. https://doi.org/10.1007/978-3-540-30181-3_1

4. Sy, D. (2007). Adapting usability investigations for agile user-centered design. Journal of usability Studies, 2(3), 112-132.

5. Ye, F., \& Wang, Z. (2013). Effects of information technology alignment and information sharing on supply chain operational performance. Computers \& Industrial Engineering, 65(3), 370-377. https://doi.org/10.1016/j.cie.2013.03.012

6. Santos, V., Goldman, A., Martins, D., \& Cortes, M. (2014, January). The Influence of Organizational Factors on Inter-team Knowledge Sharing Effectiveness in Agile Environments. In System Sciences (HICSS), 2014 47th Hawaii International Conference on (pp. 4729-4738). IEEE. https://doi.org/10.1109/hicss.2014.581

7. Santos, V., Goldman, A., \& De Souza, C. R. (2015). Fostering effective inter-team knowledge sharing in agile software development. Empirical Software Engineering, 20(4), 1006-1051. https://doi.org/10.1007/s10664-014-9307-y

8. Sparrow, P., \& Cooper, C. (2014). Organizational effectiveness, people and performance: new challenges, new research agendas. Journal of Organizational Effectiveness: People and Performance, 1(1), 2-13. https://doi.org/10.1108/joepp-01-2014-0004

9. Bryant, R. G. (2016). The Relationship of Management Support, Cash Incentives, Non-Cash Incentives, and Project Leadership to Project Success in Information Technology Organizations. Northcentral University.

10. Filicetti, J. (2009). Project Planning Overview. PM Hut (Last accessed 8 November 2009).

11. Alliance, A. (2006). What is agile software development?.

12. Zain, M., Kassim, N. M., \& Mokhtar, E. (2003). Use of information technology and information systems for organisational agility in Malaysian firms. Singapore Management Review, 25(1), 69.

13. Van Der Vyver, G., Koronios, A., \& Lane, M. (2003). Agile methodologies and the emergence of the agile organization: A software development approach waiting for its time?. PACIS 2003 Proceedings, 93.

14. Fry, C., \& Greene, S. (2007, August). Large scale agile transformation in an on-demand world. In Agile Conference (AGILE),

15. Patel, C., \& Ramachandran, M. (2009). Agile maturity model (AMM): A Software Process Improvement framework for agile software development practices. International Journal of Software Engineering, IJSE, 2(1), 3-28. https://doi.org/10.4304/jsw.4.5.422-435

16. Noor, M. A., Rabiser, R., \& Grünbacher, P. (2008). Agile product line planning: A collaborative approach and a case study. Journal of $\begin{array}{llll}\text { Systems and } \quad \text { Software, } & 81(6), & 868-882 .\end{array}$ https://doi.org/10.1016/j.jss.2007.10.028

17. Dingsøyr, T., \& Moe, N. B. (2014, May). Towards principles of large-scale agile development. In International Conference on Agile Software Development (pp. 1-8). Springer, Cham. https://doi.org/10.1007/978-3-319-14358-3_1

18. Leffingwell, D. (2010). Agile software requirements: lean requirements practices for teams, programs, and the enterprise. Addison-Wesley Professional

19. Zäh, M. F., Möller, N., \& Vogl, W. (2005, September). Symbiosis of changeable and virtual production-the emperor's new clothes or key factor for future success. In Proceedings of the 1st Conference on
Changeable, Agile, Reconfigurable and Virtual Production (CARV 2005), Munich, Germany (pp. 3-10).

20. Gunasekaran, A., \& Yusuf, Y. Y. (2002). Agile manufacturing: a taxonomy of strategic and technological imperatives. International Journal of Production Research, 40(6), 1357-1385. https://doi.org/10.1080/00207540110118370

21. Misra, S. C., Kumar, V., \& Kumar, U. (2009). Identifying some important success factors in adopting agile software development practices. Journal of Systems and Software, 82(11), 1869-1890. https://doi.org/10.1016/j.jss.2009.05.052

22. Maskell, B. (2001). The age of agile manufacturing. Supply Chain Management: An International Journal, 6(1), 5-11. https://doi.org/10.1108/13598540110380868

23. Pee, L. G., Kankanhalli, A., \& Kim, H. W. (2010). Knowledge sharing in information systems development: a social interdependence perspective. Journal of the Association for Information Systems, 11(10), 550. https://doi.org/10.17705/1 jais.00238

24. Terje Karlsen, J., Hagman, L., \& Pedersen, T. (2011). Intra-project transfer of knowledge in information systems development firms. Journal of Systems and Information Technology, 13(1), 66-80. https://doi.org/10.1108/13287261111118359

25. Dorairaj, S., Noble, J., \& Malik, P. (2012, August). Knowledge management in distributed agile software development. In Agile Conference (AGILE), 2012 (pp. 64-73). IEEE https://doi.org/10.1109/agile.2012.17

26. Yigitbasioglu, O. M. (2010). Information sharing with key suppliers: a transaction cost theory perspective. International Journal of Physical Distribution \& Logistics Management, 40(7), 550-578. https://doi.org/10.1108/09600031011072000

27. Verheij, H., \& Augenbroe, G. (2006). Collaborative planning of AEC projects and partnerships. Automation in Construction, 15(4), 428-437. https://doi.org/10.1016/j.autcon.2005.06.011

28. Karadsheh, L., Alhawari, S., El-Bathy, N., \& Hadi, W. (2008) Incorporating knowledge management and risk management as a single process. In Proceedings of International Conference of the Global Business Development Institute (GBDI) Las Vegas, NV, USA (pp. 207-214)

29. Lee, S. H., Pena-Mora, F., \& Park, M. (2006). Dynamic planning and control methodology for strategic and operational construction project management. Automation in construction, 15(1), 84-97. https://doi.org/10.1016/j.autcon.2005.02.008

30. Kaipia, R., \& Hartiala, H. (2006). Information-sharing in supply chains: five proposals on how to proceed. The International Journal of Logistics Management, 17(3), 377-393. https://doi.org/10.1108/09574090610717536

31. Verworn, B., Herstatt, C., \& Nagahira, A. (2008). The fuzzy front end of Japanese new product development projects: impact on success and differences between incremental and radical projects. R\&d Management, 38(1) https://doi.org/10.1111/j.1467-9310.2007.00492.x

32. Barlow, J. B., Giboney, J., Keith, M. J., Wilson, D., Schuetzler, R. M., Lowry, P. B., \& Vance, A. (2011). Overview and guidance on

33. Yinan, Q., Tang, M., \& Zhang, M. (2014). Mass customization in flat organization: The mediating role of supply chain planning and corporation coordination. Journal of applied research and technology, 12(2), 171-181. https://doi.org/10.1016/s1665-6423(14)72333-8

34. Cheng, T. E., \& Choi, T. M. (Eds.). (2010). Innovative quick response programs in logistics and supply chain management. Springer Science \& Business Media. https://doi.org/10.1007/978-3-642-04313-0

35. Tallon, P. P., \& Pinsonneault, A. (2011). Competing perspectives on the link between strategic information technology alignment and organizational agility: insights from a mediation model. Mis Quarterly, 463-486. https://doi.org/10.2307/23044052

36. Pettit, S., \& Beresford, A. (2009). Critical success factors in the context of humanitarian aid supply chains. International Journal of Physical Distribution \& Logistics Management, 39(6), 450-468. https://doi.org/10.1108/09600030910985811

37. Smith, T. A., Mills, A. M., \& Dion, P. (2010). Linking business strategy and knowledge management capabilities for organizational effectiveness. International Journal of Knowledge Management (IJKM), 6(3), 22-43. https://doi.org/10.4018/jkm.2010070102 
38. Santos, V., Goldman, A., \& De Souza, C. R. (2015). Fostering effective inter-team knowledge sharing in agile software development. Empirical Software Engineering, 20(4), 1006-1051. https://doi.org/10.1007/s10664-014-9307-y

39. Zwikael, O., \& Globerson, S. (2006). Benchmarking of project planning and success in selected industries. Benchmarking: An $\begin{array}{lll}\text { International } & \text { Journal, } & \text { 13(6), }\end{array}$ https://doi.org/10.1108/14635770610709059

40. Souza, C. R. D. (2012). Fostering inter-team knowledge sharing effectiveness in agile software development.

41. Benaroch, M., Lichtenstein, Y., \& Robinson, K. (2006). Real options in information technology risk management: An empirical validation of risk-option relationships. MIS quarterly, 827-864. https://doi.org/10.2307/25148756

42. De Dreu, C. K. (2007). Cooperative outcome interdependence, task reflexivity, and team effectiveness: a motivated information processing perspective. Journal of applied psychology, 92(3), 628. https://doi.org/10.1037/0021-9010.92.3.628

43. Roberts, T. L., Cheney, P. H., Sweeney, P. D., \& Hightower, R. T. (2004). The effects of information technology project complexity on group interaction. Journal of Management Information Systems, 21(3), 223-247. https://doi.org/10.1080/07421222.2004.11045814

44. Lu, Y., \& K.(Ram) Ramamurthy. (2011). Understanding the link between information technology capability and organizational agility: An empirical examination. Mis Quarterly, 931-954. https://doi.org/10.2307/41409967

45. Rand, C., \& Eckfeldt, B. (2004, June). Aligning strategic planning with agile development: Extending agile thinking to business improvement. In Agile Development Conference, 2004 (pp. 78-82). IEEE. https://doi.org/10.1109/adevc.2004.5

46. Larman, C., \& Basili, V. R. (2003). Iterative and incremental developments. a brief history. Computer, 36(6), 47-56. https://doi.org/10.1109/mc.2003.1204375

47. Gunasekaran, A., \& Yusuf, Y. Y. (2002). Agile manufacturing: a taxonomy of strategic and technological imperatives. International Journal of Production Research, 40(6), 1357-1385. https://doi.org/10.1080/00207540110118370

48. Misra, S. C., Kumar, V., \& Kumar, U. (2009). Identifying some important success factors in adopting agile software development practices. Journal of Systems and Software, 82(11), 1869-1890. https://doi.org/10.1016/j.jss.2009.05.052

49. Cheng, T. E., \& Choi, T. M. (Eds.). (2010). Innovative quick response programs in logistics and supply chain management. Springer Science \& Business Media. https://doi.org/10.1007/978-3-642-04313-0

50. Malhotra, Y. (2005). Integrating knowledge management technologies in organizational business processes: getting real time enterprises to deliver real business performance. Journal of knowledge management, 9(1), 7-28. https://doi.org/10.1108/13673270510582938

51. Uhl-Bien, M., Marion, R., \& McKelvey, B. (2007). Complexity leadership theory: Shifting leadership from the industrial age to the knowledge era. The leadership quarterly, 18(4), 298-318. https://doi.org/10.1016/j.leaqua.2007.04.002 